\title{
FORMASI ROHANI SEORANG PELAYAN ANAK DALAM \\ MENUNJANG EFEKTIVITAS PELAYANAN
}

\author{
Rosyanthi Ferayanthi Bambarehi \\ sttjaffraymakassar@yahoo.co.id \\ Ivone Patti Palar \\ ivone0lpp@yahoo.com
}

\begin{abstract}
ABSTRAK
Sesuai dengan pokok masalah yang ada, maka yang menjadi tujuan dalam penulisan karya ilmiah ini adalah: Pertama, Para pelayan anak mengerti tentang tantangan dan peperangan yang dihadapinya dalam pelayanan anak. Kedua, Para pelayan anak memiliki formasi kehidupan rohani yang benar agar siap menghadapi tantangan dan peperangan dalam pelayanan anak sehingga pelayanannya menjadi efektif. Ketiga, Sebagai salah satu syarat untuk mencapai gelar Sarjana Teologi di Sekolah Tinggi Theologia Jaffray Makassar.

Adapun metode penulisan yang digunakan dalam penulisan karya ilmiah ini untuk mendapatkan data yang diperlukan adalah: Pertama, Metode pengambilan dan pengumpulan data melalui buku-buku yang berkaitan dengan judul yang dibahas dalam karya ilmiah ini. Kedua, Dengan mengadakan wawancara dan kuisioner dengan beberappelayan anak dari jenis pelayanan anakyang berbeda.

Setelah melihat semua hasil pembahasan dari setiap bab sebelumnya, maka penulis menarik beberapa kesimpulan. Formasi rohani seorang pelayan anak mencakup hubungan yang benar dengan Tuhan, hubungan yang benar dengan sesama dan pengalaman perubahan dalam mengatasi dosa dan bertumbuh dalam kekudusan. Hubungan yang benar dengan Tuhan didasarkan pada pertobatan yang sejati dan pengalaman perjumpaan secara pribadi dengan Tuhan, yang selanjutnya akan membawa pertumbuhan yang benar, melalui waktu teduh, kehidupan doa dan puasa, serta persekutuan dan ibadah. Hubungan yang benar dengan Allah akan menghasilkan hubungan yang benar pula dengan sesama. Hubungan yang benar dengan Allah juga akan membuat seorang pelayan anak bersandar penuh pada kuasa Roh Kudus sehingga mengalami perubahan dan bertumbuh dalam kekudusan.
\end{abstract}

Kata Kunci: Formasi Rohani, Pelayan Anak dan Efektivitas Pelayanan. 


\section{PENDAHULUAN}

\section{Latar Belakang Masalah}

Kebanyakan pelayan anak menyadari perlunya memiliki skill (keterampilan) atau kemampuan dalam melayani anak dan bagaimana menghidangkan segala yang terbaik untuk anak-anak yang dilayaninya. Menjamurnya pelatihan atau lokakarya yang diadakan untuk memperlengkapi para pelayan anak dalam melayani anak, di mana mereka antusias untuk mengikutinya, telah membuktikan kesadaran tersebut di atas. Namun esensi dari pelatihan atau lokakarya tersebut acapkali menjadi kabur bahkan terlupakan. Para pelayan anak secara tidak sadar lebih mengutamakan ketrampilan atau kemampuan untuk melayani anak, dan lupa tujuan melayani atau mengajar anak. I. L Pasaribu menuliskan bahwa tujuan menyelenggarakan lokakarya guru sekolah minggu ialah menolong mereka mengajar supaya kehidupan murid-murid mereka berubah. ${ }^{1}$

Banyak buku yang ditulis mengenai bagaimana metode-metode kreatif untuk melayani anak, bagaimana menyiapkan alat peraga dan menggunakannya, bagaimana bercerita dan berbicara dengan baik kepada anak dan lain-lain. Bacaan-bacaan tersebut dapat menolong pelayan anak untuk menarik perhatian atau minat anak datang ke Sekolah Minggu. Saat ini terlalu banyak hal yang menarik perhatian anak-anak, seperti: film, internet, media elektronik, permainan elektronik, dunia digital dan lain sebagainya, di mana sadar atau tidak para pelayan anak sedang bersaing dengan semuanya itu.

Rut Laufer menuliskan bahwa, untuk menghasilkan perubahan dalam kehidupan para remaja - termasuk anak, pemimpin (pelayan anak) harus melibatkan para remaja dalam proses belajar. Proses belajar ini dapat terjadi dalam beberapa tahap pelajaran yang kreatif, maksudnya, dalam mengajar seorang pelayan anak harus memberikan pengajaran dengan metode yang kreatif. ${ }^{2}$ Namun perlu diingat oleh para pelayan anak bahwa metode mengajar hanyalah alat untuk mencapai tujuan mengajar bukan tujuan itu sendiri. Pasaribu mengatakan bahwa metode mengajar merupakan bagian integral dari suatu rencana dan tindakan mengajar. Dalam hubungan ini metode mengajar bukanlah suatu tujuan, melainkan sebagai suatu cara untuk mencapai tujuan sebaik-baiknya. ${ }^{3}$

Jika demikian, sudah semestinyalah dengan semua ketrampilan, metode dan 'hidangan' yang disiapkan oleh para pelayan anak, anak-anak

\footnotetext{
${ }^{1}$ Lelia Lewis, Mengajar Untuk Mengubah Kehidupan (Bandung: Yayasan Kalam Hidup, 1995), 3.

${ }^{2}$ Ruth Laufer, Metode-Metode Kreatif Untuk Pelayanan Remaja, (Malang: Yayasan Persekutuan Pekabaran Injil Indonesia, 1986), 14.

${ }^{3}$ I. L. Pasaribu dan B. Simanjuntak, Proses Belajar-Mengajar, (Bandung: Tarsito, 1983), 9.
} 
akan menjadi semakin tertarik mengikuti kegiatan-kegiatan yang ada, bahkan terjadi perubahan karakter dalam diri setiap anak. Tetapi kenyataannya, semua hal di atas tidak menjamin efektivitas pelayanan kepada anak-anak. Cerita yang baik, metode yang kreatif, dan alat peraga yang menarik tidak dapat menjamin tercapainya tujuan dan terjadinya suatu perubahan karakter, yang membawa anak benar-benar mengalami perjumpaan dengan Kristus.

Satu hal yang sering diabaikan atau mungkin juga tidak disadari oleh para pelayan anak bahwa masih ada satu sisi lain yang penting dari pelayanan anak, selain dari hal-hal teknis di atas, yaitu pelayanan anak selalu berhubungan dengan peperangan rohani. Tri Budiarjo dalam bukunya Sorotan Alkitab Tentang Anak, menuliskan, "Anak berada dalam pusat peperangan rohani kosmis." ${ }^{4}$. Di dalam Alkitab dijumpai beberapa contoh tentang pernyataan tersebut. Anak Hagar - Ismail, menjadi korban dari konflik kepentingan antara Sarah dan Hagar. Anak-anak laki-laki Israel menjadi korban konflik kepentingan Mesir dengan keturunan Yusuf. Mereka menjadi korban politik pengendalian pertambahan penduduk yang kejam, di mana bayi laki-laki harus dibunuh pada waktu mereka dilahirkan (Kel.1:15-22). Anak-anak Betlehem pun menjadi korban konflik kepentingan Herodes. ${ }^{5}$ Para pelayan anak perlu memahami mengapa anakanak selalu menjadi korban dalam masalah kemanusiaan, karena anak berada dalam pusat peperangan rohani

Di masa kini, dalam situasi konflik dan peperangan anak pun menjadi korban karena kehilangan perlindungan dan asuhan orang tua. Demikian juga dalam kasus perceraian, aborsi, pelecehan, juga kekerasan seksual, kekerasan fisik, kekerasan mental, bahkan penelantaran terhadap anakanak. Sadar atau tidak, ini strategi iblis untuk mengagalkan rencana Allah atas anak-anak. Dan ironisnya, banyak pelayan anak tidak menyadarinya.

Para pelayan di Pusat Pengembangan Anak Domby Kid's Hope Yogyakarta dan para mahasiswa/i STT Jaffray konsentrasi Pelayanan Anak dan Remaja yang melakukan pelayanan anak di gereja lokal, memiliki peluang untuk membina anak secara efektif. Program-program dan fasilitas pelayanan yang memadai, menarik disertai dengan berbagai keahlian juga pengetahuan, seharusnya membuat anak-anak yang dilayani tertarik mengikuti kegiatan-kegiatan yang ada. Ini memungkinkan terjadinya suatu perubahan hidup dan pertumbuhan secara rohani, mental - intelektual, sosial - emosional dan secara fisik. Namun kenyataannya, masih banyak anak yang lebih tertarik dengan berbagai hal yang disajikan oleh dunia dari pada hal-hal yang dihidangkan oleh para pelayan anak dan masih banyak anak yang tidak mengalami perubahan dan pertumbuhan secara holistik.

14.

${ }^{4}$ Tri Budiardjo, Sorotan Alkitab Tentang Anak (Jakarta: Yayasan Obor Mitra, 2001),

${ }^{5}$ Ibid, 15. 
Sebaiknya para pelayan anak tidak hanya membekali diri dengan pengetahuan, pengalaman dan hal-hal teknis saja dalam melayani anak, karena berhasilnya suatu pelayanan kepada anak tidak hanya ditentukan oleh itu semua. Hanya bergantung pada pengetahuan dan teori dalam buku saja, seorang guru tidak dapat menjadi seorang guru yang berhasil. ${ }^{6}$ Ini berlaku pula untuk semua pelayan anak. Hal yang menentukan namun sering diabaikan ialah kesiapan secara rohani seorang pelayan anak dalam menghadapi tantangan dan peperangan secara roh di dalam pelayanannya. Hal ini menyangkut tatanan atau formasi kehidupan rohani seorang pelayan anak yang menentukan keberhasilan yang memuaskan dalam pelayanan.

Berdasarkan latar belakang masalah di atas, maka penulis memilih judul karya ilmiah: "FORMASI ROHANI SEORANG PELAYAN ANAK DALAM MENUNJANG EFEKTIVITAS PELAYANAN"

\section{Masalah Pokok}

Dari latar belakang masalah di atas, maka yang menjadi masalah pokok yang akan dibahas dalam karya ilmiah ini adalah:

Pertama, Sejauh mana pelayan anak mengerti tantangan dan peperangan yang dihadapinya dalam pelayanan.

Kedua, Bagaimana para pelayan anak mempersiapkan diri dengan formasi rohani yang memadai dalam menghadapi tantangan dan peperangan tersebut, juga dalam menunjang efektivitas pelayanan.

\section{Tujuan Penulisan}

Sesuai dengan pokok masalah yang ada, maka yang menjadi tujuan dalam penulisan karya ilmiah ini adalah:

Pertama, Para pelayan anak mengerti tentang tantangan dan peperangan yang dihadapinya dalam pelayanan anak.

Kedua, Para pelayan anak memiliki formasi kehidupan rohani yang benar agar siap menghadapi tantangan dan peperangan dalam pelayanan anak sehingga pelayanannya menjadi efektif.

Ketiga, Sebagai salah satu syarat untuk mencapai gelar Sarjana Teologi di Sekolah Tinggi Theologia Jaffray Makassar.

\section{Manfaat Penuliasan}

Beberapa manfaat yang diharapkan dapat tercapai dalam penulisan karya ilmiah ini adalah:

Partama, Melalui karya ilmiah ini diharapkan para pelayan anak mengetahui dan memiliki formasi rohani yang sesungguhnya dalam menunjang pelayananya. 2005), 7 .

${ }^{6}$ Mery Go Setiawani, Pembaharuan Mengajar, (Bandung: Yayasan Kalam Hidup, 
Kedua, Dengan formasi rohani yang dimiliki oleh para pelayan anak tersebut, pelayan anak dapat menghadapi tantangan dan peperangan yang terjadi dalam pelayanan.

Ketiga, Pelayanan anak dapat berjalan dengan efektif.

\section{Metode Penulisan}

Adapun metode penulisan yang digunakan dalam penulisan karya ilmiah ini untuk mendapatkan data yang diperlukan adalah:

Pertama, Metode pengambilan dan pengumpulan data melalui bukubuku yang berkaitan dengan judul yang dibahas dalam karya ilmiah ini.

Kedua, Dengan mengadakan wawancara dan kuisioner dengan beberapa pelayan anak dari jenis pelayanan anak yang berbeda.

\section{Batasan Penulisan}

Pelayan anak yang dimaksudkan oleh penulis dalam karya ilmiah ini adalah semua yang terlibat dalam pelayanan anak (model atau bentuk apa pun). Namun dalam karya ilmiah ini, penulis akan mengambil sampel beberapa pelayan anak dari jenis pelayanan anak yang berbeda, yaitu para pelayan Pusat Pengembangan Anak Domby Kid's Hope Yogyakarta, sebagai sampel dari jenis pelayanan holistik dan mahasiswa PAR (Pelayanan Anak dan Remaja) Sekolah Tinggi Theologia Jaffray Makassar untuk mewakili para pelayan anak dari beberapa gereja lokal.

Sedangkan batasan usia untuk anak yang dimaksudkan penulis dalam karya ilmiah ini adalah anak usia 18 tahun ke bawah, sesuai dengan Konvensi Hak Anak (20 November 1989).

\section{Definisi-definisi}

Formasi Rohani

Formasi berarti suatu susunan, sedangkan rohani berarti segala sesuatu yang berhubungan dengan roh. Roh adalah sesuatu yang ada di dalam tubuh yang diberikan Tuhan sebagai penyebab adanya hidup atau kehidupan; nyawa. ${ }^{7}$

Dalam bukunya Renovation of the Heart, Dallas Willard mengatakan, Formasi spiritual bagi orang Kristen pada dasarnya mengacu pada proses yang digerakkan oleh Roh dalam membentuk dunia batiniah manusia dengan cara sedemikian rupa sehingga menjadi serupa dengan keberadaan batiniah Kristus sendiri ... Formasi spiritual Kristen difokuskan sepenuhnya kepada Yesus.

\footnotetext{
${ }^{7}$ Prof Dr. J. S. Badudu; Prof Sultan Mohammad Zain, Kamus Umum Bahasa Indonesia, (Pustaka Sinar Harapan: Jakarta, 1994), 410, 1174.

${ }^{8}$ Dallas Willard, Renovation of the Heart, (Malang: Literatur SAAT, 2005), 30.
} 
Dengan demikian, Formasi Rohani seorang pelayan anak berarti suatu susunan atau tatanan kehidupan rohani tertentu, yaitu sesuatu yang menyebabkan adanya kehidupan yang dimiliki oleh seorang pelayan anak, yang terbentuk melalui berbagai proses dalam kehidupannya yang digerakan oleh Roh, untuk membentuk suatu kehidupan batiniah dan roh yang serupa dengan Kristus.

\section{Efektivitas}

Kata dasar dari efektivitas yaitu efektif yang berarti: (1) Mempunyai efek, pengaruh, akibat, (2) memberikan hasil yang memuaskan, (3) memanfaatkan waktu dan cara dengan sebaik-baiknya, (4) Berhasil guna. ${ }^{9}$

Efektivitas dalam pelayanan anak berarti, sesuatu yang memberi efek, pengaruh, dan hasil yang maksimal dalam pelayanan tersebut.

\section{METODOLOGI PENELITIAN}

\section{Gambaran Umum Lokasi Penelitian}

Pelayanan anak yang penulis pilih sebagai sampel dari penelitian ini berada di dalam dua lokasi penelitian yang berbeda, tujuannya adalah untuk mewakili beberapa jenis pelayanan anak, baik itu pelayan anak yang melayani di beberapa denominasi gereja, maupun pelayanan anak yang melayani di bidang pelayanan anak holistik. Kedua lokasi penelitian tersebut adalah:

\section{Pusat Pengembangan Anak Domby Kid's Hope Yogyakarta}

Pusat Pengembangan Anak Domby Kid's Hope Yogyakarta Pembina. Domby Kid's Hope Yogyakarta adalah sebuah pelayanan yang mengembangkan anak-anak dari keluarga kurang mampu. Tujuan akhirnya adalah agar anak-anak yang dilayani memiliki kecakapan untuk menyelesaikan berbagai masalah dalam kehidupan sehingga mereka lepas dari kemiskinan yang selama ini mengikat mereka. Kemiskinan adalah suatu ketidakberdayaan seseorang untuk mengembangkan diri dan ketidakberdayaan seseorang dalam menghadapi permasalahan kehidupan. Sehingga kemiskinan tidak hanya terletak pada ketidakberdayaan ekonomi saja, melainkan ketidakberdayaan fisik, sosial - emosional dan spiritual, sehingga orang tersebut tidak berkembang dan bertumbuh.

DKH aktif melayani mulai bulan Februari 2002 dan bernaung di bawah Yayasan Pelita Bangsa Yogyakarta. Yayasan Pelita Bangsa

${ }^{9}$ Ibid, 371. 
Yogyakarta itu sendiri adalah lembaga yang bergerak di bidang pendidikan dan sosial. ${ }^{10}$

Visi pelayanan Domby Kid's Hope ini adalah menyelamatkan anak dan menghasilkan pemimpin yang mandiri dan berkarakter mulia. Fokus dan subyeknya adalah anak, di mana segala potensi dan sumber daya yang dimiliki akan dikelolah sebaik-baiknya untuk kepentingan anak. Bila anak tidak diselamatkan rantai kemiskinan akan terus berputar. Tubuh, jiwa dan roh anak harus diselamatkan. Domby hadir bukan untuk menghasilkan pejabat melainkan pemimpin. Pemimpin adalah orang yang mau mengambil tanggung jawab atas dirinya sendiri, orang lain bahkan bangsanya. Anak harus bertanggung jawab atas dirinya, lingkungan, kota dan bangsanya. Gol terakhir adalah anak mampu mengelolah dirinya serta mencukupi kebutuhan pribadinya (mandiri), serta berkarakter mulia sehingga dapat menjadi pengaruh positif bagi lingkungannya. ${ }^{11}$

Tenaga pelayan atau pembina dalam pelayanan ini berjumlah \pm 20 orang dengan jumlah anak yang di layani adalah 168 anak (75\% Muslim, 6 $\%$ Katotik, dan $19 \%$ Kristen). ${ }^{12}$

\section{Sekolah Tinggi Theologia Jaffray - Mahasiswa Konsentrasi PAR}

STT Jaffray - Mahasiswa/i Konsentrasi Pelayanan Anak dan Remaja (PAR). Konsentrasi PAR STT Jaffray dimulai pada tahun 2006, dengan jumlah mahasiswa pada saat itu lima orang (termasuk penulis). Dan sampai saat ini mahasiswa/i PAR berjumlah 19 orang, dengan ketua Departemen Pelayanan Anak, Ev. Elisabeth Ronda, S. Pak. Semua mahasiswa yang masuk dalam konsentrasi PAR secara umum telah memiliki pengalaman dalam pelayanan anak, baik di gereja lokal masingmasing maupun di tempat lain. PAR juga memiliki program menjangkau anak-anak dan guru/pelayan anak dengan cara membangun jejaring dengan gereja-gereja atau yayasan sosial yang bergerak di bidang pelayanan anak untuk bekerjasama dalam mengembangkan pelayanan anak di gereja-gereja maupun di bidang pelayanan anak lainnya.

\section{Jenis Penelitian}

Jenis penelitian yang digunakan oleh penulis dalam karya ilmiah ini adalah penelitian secara kuantitatif yaitu penelitian yang disajikan dalam bentuk tabel untuk menunjukan data yang jelas mengenai suatu masalah.

\footnotetext{
${ }^{10}$ Inri, Wawancara oleh Penulis, Yogyakarta, Juli 2010.

${ }^{11}$ Panduan Pembina Domby Kid's Hope 2, (Yogyakarta: Versi 1.0/2008), 2.

${ }^{12}$ Tri Nuryani, Wawancara oleh Penulis, Yogyakarta, 13 Mei 2011.
} 


\section{Populasi dan Sampel \\ Populasi}

Populasi adalah (1) seluruh jumlah orang atau penduduk di suatu daerah; (2) jumlah orang atau pribadi yang mempunyai ciri-ciri yang sama, (3) jumlah penghuni baik manusia maupun mahluk hidup lainnya pada suatu satuan ruang tertentu; (4) sekelompok orang, bendah, atau hal yang menjadi sumber pengambilan sampel; suatu kumpulan yang memenuhi syarat tertentu yang bekaitan dengan masalah penelitian. ${ }^{13}$ Dalam Kamus Riset, Populasi yaitu, semua individu yang menjadi sumber pengambilan sampel. ${ }^{14}$

Dalam karya ilmiah ini, yang menjadi populasi adalah para pelayan anak, yaitu para pembina Pusat Pengembangan Anak Domby Kid's Hope Yogyakarta, dan mahasiswa/i Sekolah Tinggi Theologia Jaffay Konsentrasi Pelayanan Anak dan Remaja, yang telah terlibat dalam pelayanan anak di gereja lokal masing-masing.

\section{Sampel}

Sampel adalah (1) Sesuatu yang digunakan untuk menunjukan sifat suatu kelompok yang lebih besar, (2) Bagian kecil yang mewakili kelompok atau keseluruhan yang lebih besar. ${ }^{15}$ Sampel yaitu sebagian dari individu yang menjadi objek penyelidikan. ${ }^{16}$

Sampel yang dipakai dalam penelitian ini adalah 10 orang pembina dari Pusat Pengembangan Anak Domby Kid's Hope Yogyakarta, dan 15 orang mahasiswa/i Sekolah Tinggi Theologia Jaffay Konsentrasi Pelayanan Anak dan Remaja yang telah terlibat dalam pelayanan anak di gereja lokal masing-masing.

\section{Prosedur Penelitian}

Untuk memperoleh data dan hasil yang akurat dalam penulisan karya ilmiah ini, maka penulis harus melakukan beberapa tahap penelitian. Prosedur tersebut adalah sebagai berikut:

\section{Tahap Persiapan}

Adapun beberapa tahap yang penulis lakukan menyangkut persiapan dalam proses penelitian yaitu:

Penentuan Judul

Judul yang dipilih oleh penulis adalah "Formasi Rohani Seorang Pelayan Anak Dalam Menunjang Efektivitas Pelayanan."

\footnotetext{
${ }^{13}$ Kamus Besar Bahasa Indonesia,_s.v. "Populasi."

${ }^{14}$ Komaruddin, Kamus Riset, "Population (2), Populasi" (Bandung: Angkasa, 1984), 203

${ }^{15}$ Kamus Besar Bahasa Indonesia,_s.v. "Sampel."

${ }^{16}$ Komaruddin, Kamus Riset, "Sample, contoh, sampel" (Bandung: Angkasa,1984), 238.
} 


\section{Alasan Memilih Lokasi Penelitian}

Penulis memilih dua lokasi penelitian, antara lain: Pusat Pengembangan Anak Domby Kid's Hope Yogyakarta - Pembina; dan Sekolah Tinggi Theologia Jaffray - Mahasiswa/i Konsentrasi Pelayanan Anak dan Remaja, dengan alasan:

Pertama, Karena jenis pelayanan anak di atas merupakan wadah penjangkauan jiwa, sebab memiliki peluang yang besar untuk menjangkau jiwa sebanyak-banyaknya bagi Kristus. Tidak hanya anak-anak, tetapi orang tua mereka.

Kedua, Penulis memilih Para Pembina Pusat Pengembangan Anak Domby Kid's Hope Yogyakarta sebagai sampel dari pelayanan anak holistik dan memilih Mahasiswa/i Konsenrtasi Pelayanan Anak dan Remaja, sebagai sampel untuk mewakili para pelayan anak dari beberapa denominasi gereja.

Ketiga, Penulis terlibat langsung di dalamnya, sebagai salah satu pembina di Pusat Pengembangan Anak Domby Kid's Hope Yogyakarta, selama melakukan Praktek Kerja Lapangan; dan sebagai salah satu mahasiswi Konsentrasi Pelayanan Anak dan Remaja Sekolah Tinggi Theologia Jaffray yang telah terlibat dalam pelayanan anak di salah satu gereja lokal.

Keempat, Penulis ingin mengamati sejauh mana para pelayan anak mengerti pentingnya anak-anak yang dilayani, menyadari berbagai tantangan dan peperangan yang dihadapi dalam pelayanan, serta memahami pentingnya formasi kehidupan rohani dalam menunjang efektivitas pelayanan.

\section{Teknik Pengumpulan Data}

Adapun teknik pengumpulan data yang penulis lakukan adalah melalui kuisioner dan wawancara.

\section{Kuisioner}

Metode kuisioner ini biasa disebut juga metode angket. ${ }^{17}$ Dalam teknik pengumpulan data ini penulis menggunakan kuisioner langsung, karena daftar pertanyaannya dikirim langsung kepada orang yang ingin dimintai pendapat, keyakinan atau diminta menceritakan tentang keadaan dirinya sendiri. Dalam penelitian ini penulis mengumpulkan data melalui pertanyan-pertanyaan dalam kuisioner yang dibagikan.

\footnotetext{
${ }^{17}$ Sutrisno Hadi, Metodologi Research 2, (Yogyakarta: Andi offset, 1990), 158.
} 


\section{Wawancara}

Wawancara merupakan salah satu metode pengumpulan data yaitu mendapatkan informasi dengan cara bertanya langsung kepada responden. ${ }^{18}$ Wawancara adalah salah satu bagian terpenting dalam setiap penelitian. Tanpa wawancara peneliti akan kehilangan informasi yang hanya dapat diperoleh dengan jalan bertanya langsung kepada responden. ${ }^{19}$ Itu sebabnya dalam penelitian ini, penulis memilih wawancara sebagai salah satu teknik pengumpulan data.

\section{Tahap Pelaksanaan}

Setelah kuisioner dan pertanyaan wawancara disiapkan, penulis mengajukannya kepada dosen pembimbing untuk dikoreksi. Setelah dikoreksi penulis memperbanyak sesuai dengan kebutuhan.

Selanjutnya penulis membawa/mengirimkan kuisioner tersebut kepada para pelayan anak dari Pusat Pangembangan Anak Domby Kid's Hope Yogyakarta, dan Pelayan Anak dan Remaja STT Jaffray Makassar.

Setelah semua kuisioner diisi dan dikembalikan, maka penulis mengecek setiap data dan menganalisanya. Kemudian memasukan setiap jawaban pada daftar tabulasi yang telah dipersiapkan.

\section{Teknik Analisis Data}

Data-data yang diperoleh melalui kuisioner yang telah isi, selanjutnya akan diolah dan dianalisis dengan cara kuantitatif yang menggunakan teknik persentase, kemudian di sajikan dalam bentuk tabel. Sedangkan hasil data wawancara akan dianalisis secara kualitatif.

Ada pun rumus teknik persentase yang digunakan dalam penelitian angket adalah sebagai berikut :

$$
\begin{array}{cl}
\%=\frac{n}{N} \times 100 \quad \text { Keterangan: }^{20} \\
\%=\text { Persentase } \\
\mathrm{n}=\text { Nilai yang diperoleh (jumlah jawaban } \\
\text { responden) } \\
\mathrm{N}=\text { Jumlah seluruh nilai }
\end{array}
$$

${ }^{18}$ Masri Singarimbun \& Sofian Effendi, Metode Penelitian Survai, (Jakarta:

LP3ES, 1985), 145.

${ }^{19}$ Ibid.

${ }^{20}$ Mohamad Ali, Penelitian Kependidikan Prosedur \& Strategi, (Bandung: Angkasa, 1985), 184. 


\section{ANALISIS HASIL PENELITIAN DAN PEMBAHASAN}

Dalam bagian ini hasil penelitian yang telah diperoleh melalui angket akan diolah dalam bentuk tabel, yang kemudian akan disajikan dalam penjelasan dari setiap tabulasi untuk mengetahui frekuensi jawaban responden dan presentasenya berdasarkan frekuensi.

Tabel 1

HUBUNGAN YANG BENAR DENGAN TUHAN

\begin{tabular}{|c|c|c|c|c|}
\hline $\begin{array}{l}\text { 1. Apakah Anda telah menerima Yesus } \\
\text { sebagai Juruselamat? }\end{array}$ & $\begin{array}{c}\mathrm{PA} \\
\mathrm{R}\end{array}$ & $\begin{array}{c}\text { DK } \\
\mathrm{H}\end{array}$ & $\begin{array}{l}\text { Jumlah } \\
\text { Jawaban } \\
\text { (n) }\end{array}$ & $\begin{array}{l}\text { Perse } \\
\text { ntase } \\
(\%)\end{array}$ \\
\hline Ya & 15 & 10 & 25 & $100 \%$ \\
\hline Kadang-kadang/ragu & - & - & - & - \\
\hline Tidak & - & - & - & - \\
\hline \multicolumn{2}{|l|}{ Jumlah (N) } & \multicolumn{2}{|r|}{25} & $100 \%$ \\
\hline $\begin{array}{c}\text { 2. Apakah anda melakukan Saat } \\
\text { Teduh setiap hari? }\end{array}$ & $\begin{array}{c}\mathrm{PA} \\
\mathrm{R}\end{array}$ & $\begin{array}{c}\text { DK } \\
\mathrm{H}\end{array}$ & $\begin{array}{l}\text { Jumlah } \\
\text { Jawaban } \\
\text { (n) }\end{array}$ & $\begin{array}{l}\text { Perse } \\
\text { ntase } \\
(\%)\end{array}$ \\
\hline $\mathrm{Ya}$ & 9 & 5 & 14 & $56 \%$ \\
\hline Kadang-kadang & 6 & 5 & 11 & $44 \%$ \\
\hline Tidak & - & - & - & - \\
\hline \multicolumn{3}{|l|}{ Jumlah (N) } & 25 & $100 \%$ \\
\hline $\begin{array}{l}\text { 3. Apakah Anda berdoa \& berpuasa } \\
\text { untuk kehidupan Anda dan } \\
\text { pelayanan anda? }\end{array}$ & $\begin{array}{c}\mathrm{PA} \\
\mathrm{R}\end{array}$ & $\begin{array}{c}\text { DK } \\
\mathrm{H}\end{array}$ & $\begin{array}{l}\text { Jumlah } \\
\text { Jawaban } \\
\text { (n) }\end{array}$ & $\begin{array}{l}\text { Perse } \\
\text { ntase } \\
(\%)\end{array}$ \\
\hline $\mathrm{Ya}$ & 5 & 7 & 12 & $48 \%$ \\
\hline Kadang-kadang & 8 & 3 & 11 & $44 \%$ \\
\hline Tidak & 2 & - & 2 & $8 \%$ \\
\hline \multicolumn{3}{|l|}{ Jumlah (N) } & 25 & $100 \%$ \\
\hline $\begin{array}{c}\text { 4. Apakah Anda selalu mengikuti } \\
\text { ibadah/persekutuan di gereja } \\
\text { lokal/di tempat lain? }\end{array}$ & $\begin{array}{c}\mathrm{PA} \\
\mathrm{R}\end{array}$ & $\begin{array}{c}\text { DK } \\
\mathrm{H}\end{array}$ & $\begin{array}{l}\text { Jumlah } \\
\text { Jawaban } \\
\text { (n) }\end{array}$ & $\begin{array}{l}\text { Perse } \\
\text { ntase } \\
(\%)\end{array}$ \\
\hline $\mathrm{Ya}$ & 11 & 10 & 21 & $84 \%$ \\
\hline Kadang-kadang & 3 & - & 3 & $12 \%$ \\
\hline Tidak & 1 & - & 1 & $4 \%$ \\
\hline \multicolumn{3}{|l|}{ Jumlah (N) } & 25 & $100 \%$ \\
\hline
\end{tabular}

Tabel 1, menunjukan bagaimana hubungan seorang pelayan anak dengan Tuhan. 
Dari pertanyaan pertama, "apakah Anda telah menerima Yesus sebagai Juruselamat ?" Persentase responden yang memberi jawaban 'ya' untuk pertanyaan ini adalah 25 orang (100\%). Ini menunjukan bahwa semua pelayan anak yang menjadi sampel dalam karya ilmiah ini telah menerima Yesus Kristus sebagai Juruselamatnya secara pribadi.

Kedua, mengenai membangun hubungan dengan Tuhan melalui Saat Teduh/Waktu Teduh, 14 orang (56\%) menjawab melakukan Saat Teduh setiap hari, dan 11 orang (44\%) kadang-kadang melakukannya. Dan tidak ada dari responden yang menjawab tidak melakukan saat teduh.

Ketiga, 12 orang (48\%) dari responden berdoa dan berpuasa untuk pelayanan dan kehidupan mereka secara pribadi. 11 orang (44\%) kadangkadang berdoa dan berpuasa, dan 2 orang (8\%) tidak pernah melakukan doa dan puasa untuk kehidupannya dan pelayanannya.

Keempat, 21 orang $(84 \%)$ dari seluruh responden selalu mengikuti ibadah/persekutuan di gereja lokal/di tempat lain, 3 orang (12\%) kadangkadang, dan 1 orang (4\%) menjawab tidak mengikuti ibadah/persekutuan di gereja lokal/di tempat lain.

Jadi, seluruh pelayan anak yang menjadi responden telah menerima Yesus sebagai Juruselamat secara pribadi. Sehingga, semua pelayan anak membangun hubungan pribadi dengan Tuhan melalui saat teduh, walaupun ada yang tidak melakukannya setiap hari atau kadang-kadang. Sedangkan dalam hal berdoa dan berpuasa, belum semua pelayan anak yang menjadi responden, melakukan doa dan puasa untuk kehidupan dan pelayanannya. Ini mungkin karena pelayan anak belum mengerti benar pentingnya doa dan puasa, khususnya dalam menghadapi pelayanan. Namun sebagian besar pelayan anak menyadari pentingnya berdoa dan berpuasa, juga melakukannya. Menyangkut ibadah dan persekutuan, sebagian besar responden selalu mengikuti ibadah dan persektuan, baik di gereja lokal maupun di tempat lain. Namun ada pula sebagian yang hanya kadangkadang beribadah dan bersekutu. Bahkan ironisnya, ada pelayan anak yang menjawab tidak mengikuti ibadah dan persekutuan baik di gereja lokal maupun di tempat lain.

Ini membuktikan bahwa belum semua pelayan anak, bahkan yang mengaku telah menerima Yesus sebagai Juruselamat, membangun hubungan pribadi yang baik dengan Tuhan melalui saat teduh, doa dan puasa, juga melalui ibadah dan persekutuan. 
Tebel 2

HUBUNGAN YANG BENAR DENGAN SESAMA

\begin{tabular}{|c|c|c|c|c|}
\hline $\begin{array}{c}\text { 1. Apakah Anda memiliki relasi } \\
\text { yang baik dengan rekan-rekan } \\
\text { sepelayanan Anda? }\end{array}$ & $\begin{array}{c}\mathrm{PA} \\
\mathrm{R}\end{array}$ & $\begin{array}{c}\text { DK } \\
\mathrm{H}\end{array}$ & $\begin{array}{l}\text { Jumlah } \\
\text { Jawaban } \\
\text { (n) }\end{array}$ & $\begin{array}{c}\text { Persentase } \\
(\%)\end{array}$ \\
\hline $\mathrm{Ya}$ & 13 & 10 & 23 & $92 \%$ \\
\hline Kadang-kadang & 2 & - & 2 & $8 \%$ \\
\hline Tidak & - & - & - & - \\
\hline \multicolumn{3}{|l|}{ Jumlah $(N)$} & 25 & $100 \%$ \\
\hline $\begin{array}{l}\text { 2. Apakah Anda memiliki } \\
\text { hubungan yang baik dengan } \\
\text { tetangga Anda? }\end{array}$ & $\begin{array}{c}\mathrm{PA} \\
\mathrm{R}\end{array}$ & $\begin{array}{c}\text { DK } \\
\mathrm{H}\end{array}$ & $\begin{array}{l}\text { Jumlah } \\
\text { Jawaban } \\
\text { (n) }\end{array}$ & $\begin{array}{c}\text { Persentase } \\
(\%)\end{array}$ \\
\hline Ya & 13 & 7 & 20 & $80 \%$ \\
\hline Kadang-kadang & 2 & 2 & 4 & $16 \%$ \\
\hline Tidak & - & 1 & 1 & $4 \%$ \\
\hline \multicolumn{3}{|l|}{ Jumlah $(N)$} & 25 & $100 \%$ \\
\hline $\begin{array}{l}\text { 3. Apakah Anda dapat bekerjasama } \\
\text { dalam pelayanan dengan semua } \\
\text { orang? }\end{array}$ & $\begin{array}{c}\mathrm{PA} \\
\mathrm{R}\end{array}$ & $\begin{array}{c}\text { DK } \\
\mathrm{H}\end{array}$ & $\begin{array}{l}\text { Jumlah } \\
\text { Jawaban } \\
(\mathrm{n})\end{array}$ & $\begin{array}{c}\text { Persentase } \\
(\%)\end{array}$ \\
\hline $\mathrm{Ya}$ & 8 & 9 & 17 & $68 \%$ \\
\hline Kadang-kadang & 7 & 1 & 8 & $32 \%$ \\
\hline Tidak & - & - & - & - \\
\hline \multicolumn{3}{|l|}{ Jumlah (N) } & 25 & $100 \%$ \\
\hline
\end{tabular}

Tabel di atas menunjukan hubungan seorang pelayan anak dengan sesama, baik itu rekan-rekan sepelayanan maupun tetangga atau komunitasnya.

Pertama, 23 orang (92\%) dari para pelayan anak yang menjadi sampel memiliki hubungan yang baik dengan rekan-rekan sepelayanannya. 2 orang (8\%) menjawab kadang-kadang.

Kedua, 20 orang ( $80 \%$ ) pelayan anak memiliki hubungan yang baik dengan tetangga/komunitasnya, 4 orang (16\%) menjawab kadang-kadang, dan 1 orang $(4 \%)$ menjawab tidak memiliki hubungan yang baik dengan tetangganya.

Ketiga, mengenai kerjasama antara seorang pelayan anak dengan rekan sepelayanannya. 17 orang (68 \%) dari pelayan anak dapat bekerjasama dengan semua orang dalam pelayanan, sedangkan 8 orang (32\%) menjawab kadang-kadang.

Hubungan yang benar dengan sesama, baik itu rekan sepelayanan maupun tetangga dalam suatu komunitas, menjadi hal yang sangat penting, yang mempengaruhi kehidupan rohani seorang pelayan anak juga 
efektivitas pelayanannya. Dari hasil penelitian ini terlihat bahwa meskipun sebagian besar dari pelayan anak yang menjadi responden memiliki relasi yang baik dengan sesama, baik itu rekan sepelayanan maupun tetangga atau komunitasnya, namun ada pula pelayan anak yang tidak selalu (kadangkadang) memiliki relasi yang baik dengan sesamanya, bahkan tidak memiliki hubungan yang baik. Hal ini mempengaruhi kerjasama antar rekan sepelayanan dalam pelayanan anak. Karena, bila ada hubungan yang tidak benar antar sesama atau rekan sepelayanan, maka kerjasama pun sulit tercapai. Akibatnya pelayanan menjadi tidak efektif.

Tabel 3

PENGALAMAN PERUBAHAN DALAM MENGATASI DOSA DAN BERTUMBUH DALAM KEKUDUSAN

\begin{tabular}{|c|c|c|c|c|}
\hline $\begin{array}{l}\text { 1. Apakah Anda bebas dari } \\
\text { kebiasaan-kebiasaan buruk } \\
\text { (merokok, miras, pornografi, } \\
\text { dll)? }\end{array}$ & $\begin{array}{c}\mathrm{PA} \\
\mathrm{R}\end{array}$ & $\begin{array}{c}\mathrm{DK} \\
\mathrm{H}\end{array}$ & $\begin{array}{l}\text { Jumlah } \\
\text { Jawaban } \\
\text { (n) }\end{array}$ & $\begin{array}{c}\text { Persentase } \\
(\%)\end{array}$ \\
\hline Ya & 13 & 9 & 22 & $88 \%$ \\
\hline Kadang-kadang/ragu & 1 & - & 1 & $4 \%$ \\
\hline Tidak & 1 & 1 & 2 & $8 \%$ \\
\hline \multicolumn{3}{|l|}{ Jumlah (N) } & 25 & $100 \%$ \\
\hline $\begin{array}{l}\text { 2. Apakah Anda menjaga } \\
\text { kekudusan di dalam } \\
\text { berpacaran, ataupun dalam } \\
\text { rumah tangga Anda? }\end{array}$ & $\begin{array}{c}\text { PA } \\
\text { R }\end{array}$ & $\begin{array}{c}\mathrm{DK} \\
\mathrm{H}\end{array}$ & $\begin{array}{l}\text { Jumlah } \\
\text { Jawaban } \\
\text { (n) }\end{array}$ & $\begin{array}{c}\text { Persentase } \\
(\%)\end{array}$ \\
\hline $\mathrm{Ya}$ & 13 & 10 & 23 & $92 \%$ \\
\hline Kadang-kadang & 2 & - & 2 & $8 \%$ \\
\hline Tidak & - & - & - & - \\
\hline \multicolumn{3}{|l|}{ Jumlah (N) } & 25 & $100 \%$ \\
\hline
\end{tabular}

Pada tabel ketiga ini, menunjukkan pengalaman seorang pelayan anak mengenai perubahan dalam mengatasi dosa dan bertumbuh dalam kekudusan.

Pertama, 22 orang (88 \%) pelayan anak bebas dari kebiasaankebiasaan buruk (merokok, miras, pornografi, dll). 1 orang (4\%) menjawab kadang-kadang, dan 2 orang (8\%) menjawab tidak terbebas dari kebiasaan-kebiasaan buruk (merokok, miras, pornografi, dll).

Kedua, 23 orang (92\%) menjaga kekudusan dalam berpacaran ataupun dalam rumah tangga, sedangkan 2 orang (8 \%) menjawab kadangkadang.

Jadi, dari data di atas dapat terlihat bahwa belum semua pelayan anak yang menjadi responden terbebas dari kebiasaan-kebiasaan buruk 
(merokok, miras, pornografi, dll), sekalipun sebagian besarnya menjawab bebas dari kebiasaan-kebiasaan buruk tersebut. Demikian pula dalam hubungan berpacaran dan dalam rumah tangga. Dari hasil wawancara langsung antara penulis dengan Angel dikatakan bahwa pergaulan seorang pelayan anak, khususnya dalam hal berpacaran akan mempengaruhi efektivitas pelayanannya. ${ }^{21}$

\section{Tabel 4}

KUALITAS KEHIDUPAN ANAK SECARA HOLISTIK Mengalami Pertumbuhan Rohani

\begin{tabular}{|c|c|c|c|c|}
\hline $\begin{array}{l}\text { 1. Apakah anak-anak didik Anda } \\
\text { menerima Yesus sebagai } \\
\text { Juruselamatnya? }\end{array}$ & $\begin{array}{c}\mathrm{PA} \\
\mathrm{R}\end{array}$ & $\begin{array}{c}\text { DK } \\
\mathrm{H}\end{array}$ & $\begin{array}{l}\text { Jumlah } \\
\text { Jawaban } \\
\text { (n) }\end{array}$ & $\begin{array}{c}\text { Persentase } \\
(\%)\end{array}$ \\
\hline $\mathrm{Ya}$ & 13 & 3 & 16 & $64 \%$ \\
\hline Kadang-kadang/ragu & 2 & 6 & 8 & $32 \%$ \\
\hline Tidak & - & 1 & 1 & $4 \%$ \\
\hline \multicolumn{3}{|l|}{ Jumlah (N) } & 25 & 100 \\
\hline $\begin{array}{l}\text { 2. Apakah Anda menuntun anak- } \\
\text { anak yang Anda layani untuk } \\
\text { menerima Yesus sebagai } \\
\text { Juruselamat dan terlibat dalam } \\
\text { hal-hal rohani? }\end{array}$ & $\begin{array}{c}\mathrm{PA} \\
\mathrm{R}\end{array}$ & $\begin{array}{c}\text { DK } \\
\mathrm{H}\end{array}$ & $\begin{array}{l}\text { Jumlah } \\
\text { Jawaban } \\
\text { (n) }\end{array}$ & $\begin{array}{c}\text { Persentase } \\
(\%)\end{array}$ \\
\hline $\mathrm{Ya}$ & 15 & 3 & 18 & $72 \%$ \\
\hline Kadang-kadang/ragu & - & 7 & 7 & $28 \%$ \\
\hline Tidak & - & - & - & - \\
\hline \multicolumn{3}{|l|}{ Jumlah } & 25 & $100 \%$ \\
\hline $\begin{array}{l}\text { 3. Apakah anak-anak } \\
\text { didik/binaan Anda mengalami } \\
\text { perubahan sikap dan karakter? }\end{array}$ & $\begin{array}{c}\mathrm{PA} \\
\mathrm{R}\end{array}$ & $\begin{array}{c}\text { DK } \\
\mathrm{H}\end{array}$ & $\begin{array}{l}\text { Jumlah } \\
\text { Jawaban } \\
\text { (n) }\end{array}$ & $\begin{array}{c}\text { Persentase } \\
(\%)\end{array}$ \\
\hline $\mathrm{Ya}$ & 8 & 7 & 15 & $60 \%$ \\
\hline Kadang-kadang & 7 & 3 & 10 & $40 \%$ \\
\hline Tidak & - & - & - & - \\
\hline \multicolumn{3}{|l|}{ Jumlah (N) } & 25 & $100 \%$ \\
\hline
\end{tabular}

Tabel 4, mengenai efektivitas pelayanan, dilihat dari segi kualitas kehidupan anak didik(binaan) yang dilayani.

\footnotetext{
${ }^{21}$ Anggel, Wawancara Oleh Penulis, (Makassar, 29 Mei 2011).
} 
Pertama, dengan pertanyaan apakah anak-anak didik Anda menerima Yesus sebagai Juruselamatnya. 16 orang (64\%) menjawab ya, 8 orang (32 $\%)$ kadang-kadang, dan 1 orang (4\%) menjawab tidak.

Kedua, 18 orang $(72 \%)$ dari pelayan anak yang menjadi sampel, menuntun anak-anak yang dilayaninya untuk menerima Yesus sebagai Juruselamat dan terlibat dalam hal-hal rohani. Sedangkan 7 orang $(28 \%)$ kadang-kadang melakukannya.

Ketiga, menyangkut perubahan sikap dan karakter anak-anak didik/binaan, 15 orang (60\%) menjawab bahwa anak-anak didik/binaannya mengalami perubahan sikap dan karakter, 10 orang (40\%) menjawab kadang-kadang.

Selain pelayan anak, yang menjadi indikator efektivitas pelayanan anak adalah anak-anak yang dilayani, dibina, atau dididik. Yang menjadi tolok ukurnya adalah apakah anak-anak yang dilayani menerima Yesus sebagai Juruselamat dalam hidupnya, dan apakah terjadi perubahan sikap, karakter dan bertumbuh baik secara rohani. Dari data yang ada, terlihat bahwa belum semua anak yang dilayani menerima Yesus sebagai Juruselamatnya dan mengalami perubahan sikap dan karakter.

Tabel 5

Mengalami Pertumbuhan Secara Mental - Intelek, Sosial - Emosional dan Fisik

\begin{tabular}{|c|c|c|c|c|}
\hline $\begin{array}{l}\text { 1. Apakah Anda menolong } \\
\text { anak-anak yang Anda layani } \\
\text { dalam pelajaran-pelajaran } \\
\text { sekolah/pelajaran umum? }\end{array}$ & $\begin{array}{c}\text { PA } \\
\text { R }\end{array}$ & $\begin{array}{c}\text { DK } \\
\mathrm{H}\end{array}$ & $\begin{array}{l}\text { Jumlah } \\
\text { Jawaban } \\
\text { (n) }\end{array}$ & $\begin{array}{c}\text { Persentase } \\
(\%)\end{array}$ \\
\hline $\mathrm{Ya}$ & 4 & 10 & 14 & $56 \%$ \\
\hline Kadang-kadang & 9 & - & 9 & $36 \%$ \\
\hline Tidak & 2 & - & 2 & $8 \%$ \\
\hline \multicolumn{3}{|l|}{ Jumlah (N) } & 25 & $100 \%$ \\
\hline $\begin{array}{l}\text { 2. Apakah Anda mengenal dengan } \\
\text { siapa anak-anak } \\
\text { didik/binaan Anda bergaul? }\end{array}$ & $\begin{array}{c}\text { PA } \\
\text { R }\end{array}$ & $\begin{array}{c}\text { DK } \\
\mathrm{H}\end{array}$ & $\begin{array}{l}\text { Jumlah } \\
\text { Jawaban } \\
\text { (n) }\end{array}$ & $\begin{array}{c}\text { Persentase } \\
(\%)\end{array}$ \\
\hline $\mathrm{Ya}$ & 2 & 2 & 4 & $16 \%$ \\
\hline Kadang-kadang & 9 & 7 & 16 & $64 \%$ \\
\hline Tidak & 4 & 1 & 5 & $20 \%$ \\
\hline \multicolumn{3}{|l|}{ Jumlah (N) } & 25 & 100 \\
\hline $\begin{array}{l}\text { 3. Apakah Anda turut } \\
\text { memenuhi kebutuhan secara } \\
\text { fisik (makanan/minuman, } \\
\text { pakaian, tempat tinggal yang } \\
\text { memadai, dll) dari anak-anak } \\
\text { yang Anda layani? }\end{array}$ & $\begin{array}{c}\text { PA } \\
\text { R }\end{array}$ & $\begin{array}{c}\text { DK } \\
\mathrm{H}\end{array}$ & $\begin{array}{l}\text { Jumlah } \\
\text { Jawaban } \\
\text { (n) }\end{array}$ & $\begin{array}{c}\text { Persentase } \\
(\%)\end{array}$ \\
\hline
\end{tabular}




\begin{tabular}{|c|c|c|c|c|}
\hline Ya & 1 & - & 1 & $4 \%$ \\
\hline Kadang-kadang & 8 & 3 & 11 & $44 \%$ \\
\hline Tidak & 6 & 7 & 13 & $52 \%$ \\
\hline Jumlah (N) & & 25 & $100 \%$ \\
\hline
\end{tabular}

Tabel 5 menjelaskan rancangan Allah, yaitu anak-anak bertumbuh seperti Yesus dalam dunia yang aman.

Pertama, 14 orang (56\%) turut menolong anak-anak binaan/didiknya dalam pelajaran-pelajaran sekolah/pelajaran umum, 9 orang (36\%) kadangkadang, dan 2 orang (8\%) tidak menolong anak-anak yang dilayaninya dalam pelajaran-pelajaran sekolah/umum.

Kedua mengenai sejauh mana pelayan anak mengenal anak dalam perkembangan sosialnya, secara khusus dalam pergaulan anak dengan orang lain. 4 orang (16\%) menjawab mengenal dengan siapa saja anak-anak didik/binaannya bergaul 16 orang (64\%) menjawab kadang-kadang mengenal dengan siapa anak-anaknya bergaul, dan 5 orang (20\%) menjawab tidak mengenal dengan siapa anak-anak didik/binaannya bergaul.

Ketiga, menyangkut kebutuhan fisik anak. 1 orang (4\%) menjawab turut memenuhi kebutuhan secara fisik (makanan/minuman, pakaian, tempat tinggal yang memadai, dll) dari anak-anak yang dilayaninya. 11 orang (44\%) menjawab kadang-kadang, dan 13 orang (52\%) menjawab tidak turut memenuhi kebutuhan secara fisik (makanan/minuman, pakaian, tempat tinggal yang memadai, dll) dari anak-anak yang dilayaninya.

Mengenai rancangan Allah bagi anak-anak untuk bertumbuh seperti Yesus dalam dunia yang aman, yaitu secara rohani, intelek, sosial, dan fisik, dapat terlihat bahwa sebagian besar pelayan anak yang menjadi responden lebih memperhatikan dan memenuhi kebutuhan anak secara rohani. Ini bukan hal yang salah, namun ada kebutuhan-kebutuhan lain yang kurang diperhatikan dan dipenuhi oleh para pelayan anak yaitu kebutuhan secara intelek, sosial dan fisik, di mana pelayan anak pun bertanggung jawab memenuhinya.

Pertumbuhan anak secara holistik bukan hanya perrtumbuhan rohani saja, tetapi juga mencakup pertumbuhan intelek, sosial dan fisik. Menjadi indikator alam efektivitas pelayanan 
Tabel 6

KESIAPAN DALAM MENGHADAPI TANTANGAN PELAYANAN

Penghambat Pertumbuhan Rohani

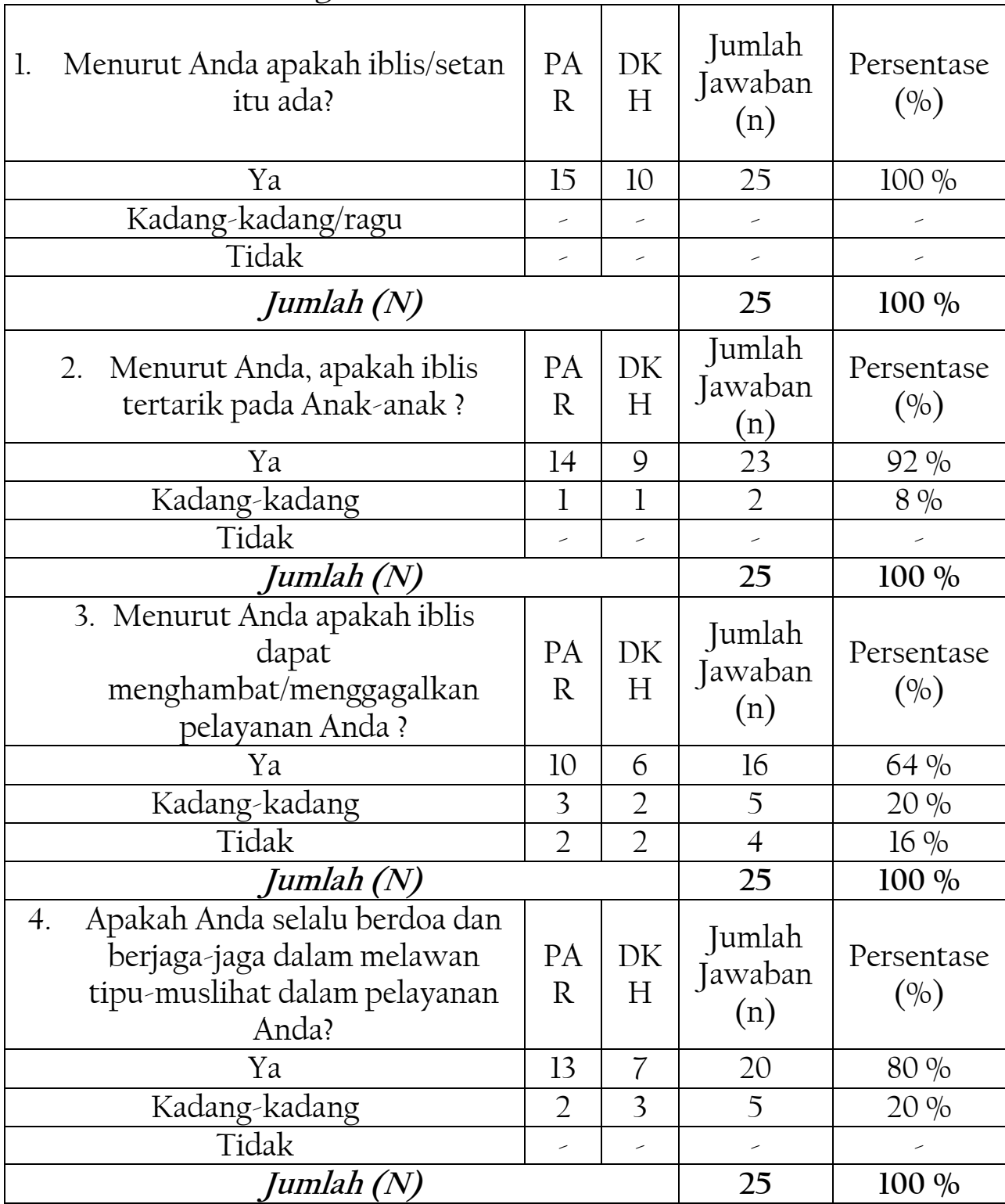

Tabel 6 mengenai sejauh mana pelayan anak menyadari strategi iblis untuk menggagalkan rancangan Allah bagi anak-anak, secara khusus dari segi kerohanian.

Pertama, 25 orang (100\%) dari pelayan anak yang menjadi sampel, menyadari bahwa iblis itu benar-benar ada. 
Kedua, 23 orang (92\%) menjawab iblis tertarik kepada anak-anak, sedangkan 2 orang ( $8 \%$ ) menjawab iblis kadang-kadang tetarik kepada anak-anak.

Ketiga, 16 orang (64\%) menjawab bahwa iblis dapat menghambat pelayanan, 5 orang (20\% )menjawab kadang-kadang, dan 4 orang (16\%) menjawab iblis tidak dapat menghambat/menggagalkan pelayanan.

Keempat, dari semua responden yang menyadari adanya iblis, 20 orang $(80 \%)$ berdoa dan berjaga-jaga dalam melawan tipu-muslihat iblis dalam pelayanan, sedangkan 5 orang (20\%) menjawab kadang-kadang.

Jadi, para pelayan anak yang menjadi responden menyadari bahwa iblis benar-benar ada dan tertarik pada anak-anak. Sehingga iblis bisa saja menghambat pelayanan, apabila pelayan anak tidak selalu berdoa dan berjaga-jaga dalam melawan tipu muslihatnya. Seorang pelayan anak perlu meningkatkan intensitas dan kualitas doanya, untuk selalu berjaga-jaga terhadap tipu muslihat dan serangan iblis di dalam pelayanannya. ${ }^{22}$

${ }^{22}$ Angel, Wawancara Oleh Penulis, (Makassar, 29 Mei 2011) 
Tabel 7

Penghambat Perkembangan Mental - Intelek, Sosial - Emosi, dan Fisik

\begin{tabular}{|c|c|c|c|c|}
\hline $\begin{array}{l}\text { 1. Apakah semua anak-anak yang } \\
\text { Anda layani memperoleh } \\
\text { pendidikan formal dan informal } \\
\text { yang memadai? }\end{array}$ & $\begin{array}{c}\mathrm{PA} \\
\mathrm{R}\end{array}$ & $\begin{array}{c}\text { DK } \\
\mathrm{H}\end{array}$ & $\begin{array}{l}\text { Jumlah } \\
\text { Jawaban } \\
\text { (n) }\end{array}$ & $\begin{array}{c}\text { Persentase } \\
(\%)\end{array}$ \\
\hline $\mathrm{Ya}$ & 7 & 9 & 16 & $64 \%$ \\
\hline Kadang-kadang & 6 & - & 6 & $24 \%$ \\
\hline Tidak & 2 & 1 & 3 & $12 \%$ \\
\hline \multicolumn{3}{|l|}{ Jumlah (N) } & 25 & $100 \%$ \\
\hline $\begin{array}{l}\text { 2. Menurut Anda, adakah anak } \\
\text { yang 'bodoh'? }\end{array}$ & $\begin{array}{c}\mathrm{PA} \\
\mathrm{R}\end{array}$ & $\begin{array}{c}\text { DK } \\
\mathrm{H}\end{array}$ & $\begin{array}{c}\text { Jumlah } \\
\text { Jawaban } \\
\text { (n) }\end{array}$ & $\begin{array}{l}\text { Persentase } \\
(\%)\end{array}$ \\
\hline $\mathrm{Ya}$ & 1 & - & 1 & $4 \%$ \\
\hline Kadang-kadang & 1 & 2 & 3 & $12 \%$ \\
\hline Tidak & 13 & 8 & 21 & $84 \%$ \\
\hline \multicolumn{3}{|l|}{ Jumlah (N) } & 25 & $100 \%$ \\
\hline $\begin{array}{l}\text { 3. Apakah anak-anak yang Anda } \\
\text { layani memiliki lingkungan } \\
\text { sosial yang baik untuk } \\
\text { pertumbuhan sosial-emosi } \\
\text { mereka? }\end{array}$ & $\begin{array}{c}\mathrm{PA} \\
\mathrm{R}\end{array}$ & $\begin{array}{c}\mathrm{DK} \\
\mathrm{H}\end{array}$ & $\begin{array}{l}\text { Jumlah } \\
\text { Jawaban } \\
\text { (n) }\end{array}$ & $\begin{array}{c}\text { Persentase } \\
(\%)\end{array}$ \\
\hline $\mathrm{Ya}$ & 6 & 1 & 7 & $28 \%$ \\
\hline Kadang-kadang & 5 & 4 & 9 & $36 \%$ \\
\hline Tidak & 4 & 5 & 9 & $36 \%$ \\
\hline \multicolumn{3}{|l|}{ Jumlah } & 25 & $100 \%$ \\
\hline $\begin{array}{l}\text { 4. Apakah Anda pernah } \\
\text { melakukan kekerasan secara } \\
\text { verbal kepada anak (memarah- } \\
\text { marahi, kata-kata kasar), } \\
\text { kekerasan emosi (mengabaikan } \\
\text { perasaan anak) atau kekerasan } \\
\text { fisik (mencubit, menampar, } \\
\text { memukul, menendang, dll)? }\end{array}$ & $\begin{array}{c}\mathrm{PA} \\
\mathrm{R}\end{array}$ & $\begin{array}{c}\text { DK } \\
\mathrm{H}\end{array}$ & $\begin{array}{l}\text { Jumlah } \\
\text { Jawaban } \\
\text { (n) }\end{array}$ & $\begin{array}{c}\text { Persentase } \\
(\%)\end{array}$ \\
\hline $\mathrm{Ya}$ & - & - & - & \\
\hline Kadang-kadang & 5 & 1 & 6 & $24 \%$ \\
\hline Tidak & 10 & 9 & 19 & $76 \%$ \\
\hline \multicolumn{3}{|l|}{ Jumlah (N) } & 25 & $100 \%$ \\
\hline
\end{tabular}


Tabel 7, mengenai sejauh mana pelayan anak menyadari strategi iblis untuk menggagalkan rancangan Allah bagi anak-anak, secara khusus dari segi mental - intelek, sosial - emosi, dan fisik.

Pertama, dari segi mental-intelek, dengan pertanyaan apakah semua anak-anak yang Anda layani memperoleh pendidikan formal dan informal yang memadai, 16 orang (64\%) menjawab ya, 6 orang (24\%) menjawab kadang-kadang dan 3 orang (12\%) menjawab tidak.

Kedua, dengan pertanyaan adakah anak yang bodoh, 1 orang (4\%) menjawab ya, 3 orang (12\%) menjawab kadang-kadang, dan 21 orang (84 $\%)$ menjawab tidak ada anak yang bodoh.

Ketiga, dari segi sosial dengan pertanyaan apakah anak-anak yang Anda layani memiliki lingkungan sosial yang baik untuk pertumbuhan sosial-emosi mereka, 7 orang (28\%) menjawab ya, 9 orang (36\%) menjawab kadang-kadang, sedangkan 9 orang (36\%) lainnya menjawab tidak.

Keempat, dengan pertanyaan, apakah Anda pernah melakukan kekerasan secara verbal kepada anak (memarah-marahi, kata-kata kasar), kekerasan emosi (mengabaikan perasaan anak) atau kekerasan fisik (mencubit, menampar, memukul, menendang, dll), dari semua responden, tidak ada yang menjawab ya, 6 orang $(24 \%)$ yang menjawab kadangkadang melakukannya, dan 19 orang $(76 \%)$ menjawab tidak pernah melakukannya.

Jadi, secara intelektual tidak semua anak memperoleh pendidikan secara formal dan informal yang memadai, namun para pelayan anak menyadari bahwa tidak ada anak yang bodoh. Dari hasil wawancara langsung antara penulis dengan Esti, dikatakan bahwa anak tidak dapat dikatakan bodoh hanya karena ia tidak dapat mengerjakan soal matematika atau pelajaran sekolah lainnya, karena setiap anak memiliki kecerdasannya masing-masing. ${ }^{23}$ Menurut data yang ada, pelayan anak juga dapat mengetahui bahwa, tidak semua anak memiliki lingkungan sosial yang baik untuk pertumbuhan sosial-emosi mereka. Hal ini dapat menjadi strategi iblis dalam menghambat rancangan Allah bagi anak-anak. Demikian halnya dengan tindakan kekerasan dalam bentuk fisik, verbal atau pun emosi/mental. Dari keterangan di atas sebagian besar pelayan anak tidak melakukan tindakan kekerasan dalam bentuk apapun terhadap anak.

${ }^{23}$ Esti, Wawancara Oleh Penulis (Makassar, 28 Mei 2011). 


\section{Tabel 8}

INDIKATOR EFEKTIVITAS PELAYANAN

Panggilan Seorang Pelayan Anak

\begin{tabular}{|c|c|c|c|c|}
\hline $\begin{array}{l}\text { 1. Apakah Anda yakin terpanggil } \\
\text { sebagai seorang pelayan anak ? }\end{array}$ & $\begin{array}{c}\mathrm{PA} \\
\mathrm{R}\end{array}$ & $\begin{array}{c}\text { DK } \\
\mathrm{H}\end{array}$ & $\begin{array}{l}\text { Jumlah } \\
\text { Jawaban } \\
\text { (n) }\end{array}$ & $\begin{array}{l}\text { Persentase } \\
\quad(\%)\end{array}$ \\
\hline $\mathrm{Ya}$ & 15 & 10 & 25 & $100 \%$ \\
\hline Kadang-kadang/ragu & - & - & - & - \\
\hline Tidak & - & - & - & - \\
\hline \multicolumn{3}{|l|}{ Jumlah (N) } & 25 & $100 \%$ \\
\hline $\begin{array}{l}\text { 2. Apakah Anda memiliki } \\
\text { keahlian khusus dalam } \\
\text { melayani anak? }\end{array}$ & $\begin{array}{c}\text { PA } \\
\text { R }\end{array}$ & $\begin{array}{c}\text { DK } \\
\mathrm{H}\end{array}$ & $\begin{array}{c}\text { Jumlah } \\
\text { Jawaban } \\
\text { (n) }\end{array}$ & $\begin{array}{l}\text { Persentase } \\
\quad(\%)\end{array}$ \\
\hline $\mathrm{Ya}$ & 11 & 7 & 18 & $72 \%$ \\
\hline Kadang-kadang & 4 & 2 & 6 & $24 \%$ \\
\hline Tidak & - & 1 & 1 & $4 \%$ \\
\hline \multicolumn{3}{|l|}{ Jumlah (N) } & 25 & $100 \%$ \\
\hline $\begin{array}{c}\text { 3. Apakah Anak-anak penting } \\
\text { bagi Anda? }\end{array}$ & $\begin{array}{c}\text { PA } \\
\mathrm{R}\end{array}$ & $\begin{array}{c}\text { DK } \\
\mathrm{H}\end{array}$ & $\begin{array}{c}\text { Jumlah } \\
\text { Jawaban } \\
\text { (n) }\end{array}$ & $\begin{array}{l}\text { Persentase } \\
\quad(\%)\end{array}$ \\
\hline $\mathrm{Ya}$ & 15 & 10 & 25 & $100 \%$ \\
\hline Kadang-kadang & - & - & - & - \\
\hline Tidak & - & - & - & - \\
\hline \multicolumn{3}{|l|}{ Jumlah (N) } & 25 & $100 \%$ \\
\hline
\end{tabular}

Tabel 8 menunjukan bagimana panggilan seorang pelayan anak.

Pertama, 25 orang (100\%) dari responden yakin terpanggil sebagai seorang pelayan anak.

Kedua, dari semua responden yang yakin akan panggilannya sebagai pelayan anak, tedapat 18 orang (72\%) menjawab bahwa mereka memiliki keahlian khusus dalam melayani anak, 6 orang (20\%) menjawab kadangkadang dan 1 orang (4\%) menjawab tidak memiliki keahlian khusus dalam melayani anak.

Ketiga, menyangkut bagaimana seorang pelayan anak memandang anak-anak. 25 orang (100 \%) menjawab bahwa anak-anak adalah penting bagi mereka.

Jadi, seluruh pelayan anak yang menjadi responden yakin akan panggilannya dalam pelayanan anak. Namun tidak semua dari mereka yang yakin akan panggilannya menjawab memiliki keahlian khusus dalam melayani anak. Semua pelayan anak memandang penting anak-anak. Seorang pelayan anak yang benar-benar terpanggil tidak hanya memandang 
anak-anak penting, tetapi juga selalu bersungguh-sungguh dalam pelayanan, tidak menolak pelayanan yang dipercayakan, tulus, tidak datang terlambat, mempersiapkan diri sebelum melayani, bersedia dievaluasi dan selalu memberikan yang tarbaik untuk Tuhan melalui anak-anak yang dilayaninya. ${ }^{24}$

Tabel 9

Menjadi Teladan, Mengenal Anak Didik, Persiapan Yang Maksimal, Kreatifitas

\begin{tabular}{|c|c|c|c|c|}
\hline $\begin{array}{c}\text { 1. Apakah Anda menerapkan } \\
\text { semua yang Anda ajarkan } \\
\text { kepada anak-anak? }\end{array}$ & $\begin{array}{c}\mathrm{PA} \\
\mathrm{R}\end{array}$ & $\begin{array}{c}\text { DK } \\
\mathrm{H}\end{array}$ & $\begin{array}{l}\text { Jumlah } \\
\text { Jawaban } \\
\text { (n) }\end{array}$ & $\begin{array}{c}\text { Persentase } \\
(\%)\end{array}$ \\
\hline $\mathrm{Ya}$ & 8 & 6 & 14 & $56 \%$ \\
\hline Kadang-kadang & 7 & 4 & 11 & $44 \%$ \\
\hline Tidak & - & - & - & - \\
\hline \multicolumn{3}{|l|}{ Jumlah (N) } & 25 & $100 \%$ \\
\hline $\begin{array}{l}\text { 2. Apakah Anda mengenal setiap } \\
\text { anak yang Anda layani sebagai } \\
\text { seorang pribadi, bukan hanya } \\
\text { sebagai seorang anak } \\
\text { didik/binaan? }\end{array}$ & $\begin{array}{c}\mathrm{PA} \\
\mathrm{R}\end{array}$ & $\begin{array}{c}\text { DK } \\
\mathrm{H}\end{array}$ & $\begin{array}{l}\text { Jumlah } \\
\text { Jawaban } \\
\text { (n) }\end{array}$ & $\begin{array}{c}\text { Persentase } \\
(\%)\end{array}$ \\
\hline $\mathrm{Ya}$ & 8 & 6 & 14 & $56 \%$ \\
\hline Kadang-kadang & 7 & 3 & 10 & $40 \%$ \\
\hline Tidak & - & 1 & 1 & $4 \%$ \\
\hline \multicolumn{3}{|l|}{ Jumlah (N) } & 25 & $100 \%$ \\
\hline $\begin{array}{l}\text { 3. Apakah Anda menguasai semua } \\
\text { pelajaran yang akan Anda } \\
\text { sampaikan sehingga Anda tidak } \\
\text { bergantung pada buku panduan } \\
\text { Anda? }\end{array}$ & $\begin{array}{c}\mathrm{PA} \\
\mathrm{R}\end{array}$ & $\begin{array}{c}\text { DK } \\
\mathrm{H}\end{array}$ & $\begin{array}{l}\text { Jumlah } \\
\text { Jawaban } \\
\text { (n) }\end{array}$ & $\begin{array}{c}\text { Persentase } \\
(\%)\end{array}$ \\
\hline $\mathrm{Ya}$ & 8 & 3 & 11 & $44 \%$ \\
\hline Kadang-kadang & 7 & 6 & 13 & $52 \%$ \\
\hline Tidak & - & 1 & 1 & $4 \%$ \\
\hline \multicolumn{3}{|l|}{ Jumlah (N) } & 25 & $100 \%$ \\
\hline $\begin{array}{l}\text { 4. Apakah Anda/Yayasan } \\
\text { pendidikan/sosial/Sekolah } \\
\text { Minggu Anda menggunakan } \\
\text { materi yang sisematis, memiliki } \\
\text { kurikulum, buku pedoman dan } \\
\text { alat peraga untuk mengajar? }\end{array}$ & $\begin{array}{c}\mathrm{PA} \\
\mathrm{R}\end{array}$ & $\begin{array}{c}\text { DK } \\
\mathrm{H}\end{array}$ & $\begin{array}{l}\text { Jumlah } \\
\text { Jawaban } \\
\text { (n) }\end{array}$ & $\begin{array}{c}\text { Persentase } \\
(\%)\end{array}$ \\
\hline
\end{tabular}

${ }^{24}$ Esti, Wawancara Oleh Penulis, (Makassar, 28 Mei 2011). 


\begin{tabular}{|c|c|c|c|c|}
\hline Ya & 10 & 8 & 18 & $72 \%$ \\
\hline Kadang-kadang & 4 & 2 & 6 & $24 \%$ \\
\hline Tidak & 1 & - & 1 & $4 \%$ \\
\hline Jumlah (N) & & 25 & $100 \%$ \\
\hline
\end{tabular}

Tabel 9 mengenai efektivitas pelayanan, dilihat dari segi seorang pelayan anak, yaitu menyangkut teladan, mengenal anak didik, persiapan yang maksimal, kreatifitas.

Pertama, mengenai teladan seorang pelayan anak, 14 orang $(56 \%)$ pelayan anak menerapkan semua yang diajarkan kepada anak-anak, dan 11 orang (44\%) kadang-kadang menerapkan apa yang diajarkannya kepada anak-anak.

Kedua, mengenai hubungan seorang pelayan anak dengan anak didik/binaannya, dengan pertanyaan apakah pelayan anak mengenal setiap anak yang dilayani sebagai seorang pribadi, bukan hanya sebagai seorang anak didik/binaan. 14 orang (56) \% menjawab ya, 10 orang (40\%) menjawab kadang-kadang, dan 1 orang (4\%) menjawab tidak.

Ketiga, mengenai persiapan yang maksimal dari seorang pelayan anak, 11 orang $(44 \%)$ pelayan anak menguasai semua pelajaran yang akan disampaikannya sehingga ia tidak bergantung pada buku panduan, 13 orang (52\%) kadang-kadang, dan 1 orang (4\%) menjawab tidak menguasai pelajaran yang disampaikannya.

Keempat, dengan pertanyaan, apakah pelayan anak Yayasan pendidikan/sosial/Sekolah Minggu, menggunakan materi yang sisematis, memiliki kurikulum, buku pedoman dan alat peraga untuk mengajar. 18 orang ( $72 \%)$ menjawab ya, 6 orang ( $24 \%$ ) menjawab kadang-kadang, dan 1 orang (4\%) menjawab tidak menggunakan semua hal di atas untuk menunjang kreativitas dan efektivitas pelayanan.

Indikator efektivitas pelayanan anak pertama-tama dapat dilihat dari teladan seorang pelayan anak, bagaimana seorang pelayan anak mengenal anak didiknya, bagaimana persiapan dan kreatifitas dari seorang pelayan anak. Dari data yang diperoleh, dapat terlihat bahwa dalam hal teladan, ternyata belum semua dari pelayan anak yang menjadi responden menerapkan semua hal yang ia ajarkan kepada anak-anak. Namun sebagian besar dari pelayan anak mengenal setiap anak yang dilayani sebagai seorang pribadi, bukan hanya sebagai seorang anak didik/binaan. Dalam hal persiapan pelayanan, sebagian besar pelayan anak tidak selalu/kadangkadang mempersiapkan dan menguasai pelajaran yang akan disampaikan kepada anak-anak didil/binaannya. Meskipun sebagian besar menjawab menggunakan materi yang sisematis, memiliki kurikulum, buku pedoman dan alat peraga untuk mengajar. 


\section{Kesimpulan Analisis}

Setelah menganalisis dan menginterpretasi data pada setiap tabel, maka selanjutnya penulis menarik beberapa kesimpulan sehubungan dengan formasi rohani pelayan anak dalam menunjang efektivitas pelayanannya.

Pertama, belum semua pelayan anak, bahkan yang mengaku telah menerima Yesus sebagai Juruselamat bertumbuh melalui hubungan pribadi yang benar dengan Tuhan dengan melakukan waktu teduh, doa dan puasa, serta ibadah dan persekutuan. Hubungan yang benar atau intim dengan Tuhan merupakan hal yang fundamental dalam menunjang efektivitas pelayanan. Bila pelayan anak memiliki hubungan yang benar atau intim dengan Tuhan, maka kuasa dan penyertaan Tuhan ada bersamanya sehingga pelayanannya akan menjadi efektif. Oleh sebab itu, untuk memiliki hubungan pribadi yang benar dengan Tuhan, maka seorang pelayan anak harus dituntun pada pertobatan yang benar dengan proses yang benar. Yaitu mulai dengan menyadari keberadaan dirinya sebagai manusia berdosa, mengakui dosa, membuka hati untuk mengundang Yesus masuk, meninggalkan dosa, dan berbalik mengikuti Yesus. Gembala atau pembina pelayan anak dapat menuntun para pelayan anak memiliki hubungan yang benar dengan Tuhan melalui lokakarya atau pertemuan pertemuan khusus para pelayan anak yang dilakukan secara berkala, karena hal ini merupakan hal yang paling mendasar yang menentukan efektivitas kehidupan dan pelayanan seorang pelayan anak.

Kedua, meskipun sebagian besar dari pelayan anak yang menjadi responden memiliki relasi yang benar dengan sesama, baik itu rekan sepelayanan maupun tetangga atau komunitasnya, namun ada pula pelayan anak yang tidak selalu (kadang-kadang), bahkan tidak memiliki relasi yang benar dengan sesamanya. Padahal, hubungan atau relasi dengan sesama akan mempengaruhi kerjasama antar rekan sepelayanan dalam menunjang efektivitas pelayanan anak. Seorang yang mengalami pertobatan yang benar dan bertumbuh akan mengalami pembaharuan dalam hubungannya dengan sesama. Hubungan yang benar dengan Allah akan menghasilkan hubungan yang benar pula dengan sesama. Jadi, para pelayan anak yang tidak memiliki relasi yang baik dengan sesama atau rekan sepelayanan, perlu memeriksa kehidupan rohaninya atau hubungan pribadinya dengan Tuhan. Cara mengobati hubungan yang tidak benar antar sesama atau rekan sepelayanan, hanyalah dengan memiliki hubungan yang benar dengan Tuhan. Hubungan yang benar dengan Tuhan didasarkan pada pertobatan yang benar. Setelah hal yang terpenting di atas, secara teknis pelayan anak dapat dibekali dengan pelajaran khusus mengenai social relationship (hubungan sosial) untuk semakin memperlengkapi para pelayan anak ketika berada bersama dalam pelayanan, maupun di dalam lingkungan sosialnya. 
Ketiga, Meskipun sebagian besar menjawab bebas dari kebiasaan buruk (merokok, miras, pornografi, dll) dan menjaga kekudusan, namun belum semua pelayan anak yang menjadi responden menjawab bebas dari kebiasaan-kebiasaan buruk tersebut, dan juga menjaga kekudusan dalam hubungan berpacaran dan rumah tangga. Untuk terbebas dari kebiasaan buruk di atas seorang pelayan anak harus sungguh-sungguh bertobat (dengan proses yang telah diuraikan pada bagian pertama) dan menyerahkan hidupnya setiap hari kepada Tuhan untuk dituntun dan dikendalikan oleh Roh Kudus, serta hidup sesuai firman-Nya (Mazmur 119:9). Dengan demikian seorang pelayan anak dapat dipakai dengan efektif oleh Allah. Hidup kudus setiap hari merupakan formasi rohani pelayan anak yang dapat menunjang efektivitas pelayanannya.

Keempat, para pelayan anak yang menjadi responden memandang anak-anak adalah penting. Mereka yakin akan panggilannya sebagai seorang pelayan anak, dan memiliki keahlian khusus dalam melayani anak. Adalah penting bagi seorang pelayan anak memiliki panggilan pelayanan dan keterampilan khusus dalam melayani untuk menunjang efektivitas pelayanannya. Keyakinan akan panggilan ini hanya diperoleh dari keintiman dalam hubungan yang benar dengan Tuhan. Ketrampilan khusus dapat dimiliki dengan mengikuti pelatihan-pelatihan atau lokakaryalokakarya pelayanan anak.

Kelima, sebagian besar pelayan anak nampaknya belum memahami bagaimana rancangan Allah bagi anak-anak, yaitu supaya anak-anak bertumbuh seperti Yesus secara holistik (rohani, intelek, sosial, fisik) dalam dunia yang aman. Hal ini menyebabkan para pelayan anak yang menjadi responden lebih memperhatikan dan memenuhi kebutuhan anak secara rohani namun kurang memperhatikan dan memenuhi kebutuhan anak secara intelek, sosial dan fisik. Padahal pelayanan yang efektif akan terjadi bila seorang pelayan anak dapat memenuhi pertumbuhan anak secara holistik baik secara rohani maupun secara intelektual, sosial-emosional dan fisik. Untuk itu, seorang pelayan anak perlu membekali dirinya dengan pengetahuan-pengetahuan tentang kebutuhan anak secara holistik. Ini dapat dilakukan dengan membaca buku-buku yang menyangkut karakteristik dan kebutuhan anak, ataupun mengikuti seminar/lokakarya mengenai pelayanan anak.

Keenam, pelayan anak yang menjadi responden menyadari bahwa Iblis benar-benar ada, dan tertarik pada anak-anak. Iblis bisa saja menghambat pelayanan, apabila pelayan anak tidak selalu berdoa dan berjaga-jaga dalam melawan tipu muslihatnya. Bila Allah merancangkan pertumbuhan anak secara rohani, intelek, sosial-emosional, dan fisik, maka iblis mengatur berbagai strategi untuk menghambat rancangan Allah tersebut. Oleh sebab itu, pelayan anak harus sungguh-sungguh menjaga kehidupan rohaninya, membentengi dirinya dengan mengenakan seluruh perlengkapan senjata Allah (Efesus 6:10-18), memegang teguh firman Tuhan 
agar dapat melawan tipu muslihat iblis (Matius 4:1-11). Selain itu, para pelayan anak perlu menyiapkan waktu untuk berdoa dan berpuasa secara khusus bagi pelayanannya dan anak-anak yang ia layani.. doa dan puasa ini dapat dilakukan secara pribadi maupun kelompok. Gereja perlu memfasilitasi kegiatan doa dan puasa secara regular atau berkala, supaya para pelayan anak memiliki kehidupan doa dan puasa yang benar-benar dijiwainya.

Ketujuh, Sekalipun dalam data yang diperoleh, terlihat bahwa para pelayan anak menjawab bahwa anak-anak didik/binaannya menerima Yesus dan mengalami pertobatan serta mengalami perubahan hidup dan pertumbuhan secara holistik, namun pelayanan anak belum dapat dikatakan benar-benar efektif. Hal tersebut dapat dilihat dari beberapa indikator yang menunjukan panggilan, teladan, pengenalan terhadap anak didik, persiapan yang maksimal, kreatifitas seorang pelayan anak, belum benar-benar tercapai. Dengan demikian maka dari segi pertumbuhan rohani, perkembangan mental - intelek, sosial - emosional, dan fisik anak didik/binaan besar kemungkinan menjadi tidak efektif. Efektivitas pelayanan akan terlihat dari kualitas kehidupan anak-anak yang dilayani. Namun, kualitas kehidupan anak-anak ditentukan oleh kualitas kehidupan pelayan anak dan kesiapannya dalam menghadapi tantangan pelayanan. Jadi, agar pelayanan benar-benar efektif, pelayan anak harus memiliki formasi kehidupan rohani yang benar, yang dimulai dari pertobatan sejati dan perjumpaan secara pribadi dengan Tuhan sehingga pelayan anak pun memiliki hubungan yang benar dengan Tuhan, sesama dan memiliki kehidupan yang bertumbuh dalam kekudusan. Dengan demikian dalam pelayanannya ia dapat menjalani panggilannya dengan penuh keyakinan , menjadi teladan, sanggup mengenali setiap anak yang dilayaninya sebagai seorang pribadi dan mampu mempersiapkan pelayanan dengan maksimal dan kreatif.

\section{Kesimpulan}

\section{PENUTUP}

Setelah melihat semua hasil pembahasan dari setiap bab sebelumnya, maka penulis menarik beberapa kesimpulan.

Pertama, Formasi rohani seorang pelayan anak mencakup hubungan yang benar dengan Tuhan, hubungan yang benar dengan sesama dan pengalaman perubahan dalam mengatasi dosa dan bertumbuh dalam kekudusan.

Kedua, Hubungan yang benar dengan Tuhan didasarkan pada pertobatan yang sejati dan pengalaman perjumpaan secara pribadi dengan Tuhan, yang selanjutnya akan membawa pertumbuhan yang benar, melalui waktu teduh, kehidupan doa dan puasa, serta persekutuan dan ibadah. Hubungan yang benar dengan Allah akan menghasilkan hubungan yang benar pula dengan sesama. Hubungan yang benar dengan Allah juga akan 
membuat seorang pelayan anak bersandar penuh pada kuasa Roh Kudus sehingga mengalami perubahan dan bertumbuh dalam kekudusan

Ketiga, Indikator suatu pelayanan anak yang efektif pertama dapat dilihat melalui kehidupan seorang pelayan anak yang memiliki keyakinan akan panggilannya didasarkan pada pertobatan yang sejati dan pengalaman lahir baru; dapat menjadi teladan dalam perkataan, tingkah laku, kasih, kesetiaan, dan kesucian; mengenal anak didiknya sebagai seorang pribadi; serta mempersiapkan pelayanan yang maksimal dan kreatif.

Keempat, Indikator efektivitas pelayanan yang kedua dapat dilihat dari kualitas kehidupan anak didik yang mengalami pertumbuhan secara holistik, yaitu secara rohani, mental - intetek, sosial - emosional, dan secara fisik.

Kelima, Indikator efektivitas pelayanan anak yang ketiga yaitu kesiapan seorang pelayan anak dalam menghadapi tantangan pelayanan secara holistik, yaitu tantangan dalam membina kerohanian anak, tantangan dalam membentuk mental - intelektual anak, tantangan dalam mengembangkan sosial - emosional anak, dan tantangan dalam memenuhi kebutuhan anak secara fisik. serta strategi dalam menghadapi tantangan pelayanan secara holistik.

\section{Saran}

Melalui karya ilmiah ini, penulis ingin menyampaikan beberapa saran sehubungan dengan formasi rohani pelayan anak dalam menunjang efektivitas pelayanan.

Pertama, Perlu bagi gembala atau pembina pelayan anak untuk memastikan bahwa semua pelayan anak telah mengalami perjumpaan secara pribadi dengan Kristus, dan memiliki hubungan yang benar dengan Tuhan, yang didasarkan pada pertobatan yang sejati.

Kedua, Para pelayan anak perlu menyadari bahwa memiliki keterampilan dan keahlian khusus dalam pelayanan anak, tidak menjamin efektivitas pelayanannya. Efektivitas pelayanan anak dapat tercapai karena memiliki suatu formasi rohani yang benar.

Ketiga, Para pelayan anak yang telah memiliki hubungan yang benar dengan Tuhan, akan memiliki kehausan untuk melayani anak-anak dengan maksimal. Untuk mencapai potensi maksimal tersebut, maka pelayan anak perlu melengkapi diri dengan membaca buku-buku yang berkaitan dengan anak, mengikuti pelatihan-pelatihan/lokakarya-lokakarya dan terbuka untuk belajar dengan rekan pelayan lainnya.

Keempat, Tantangan pelayan anak masa kini sangat kompleks. Televisi, internet, playstation, games, komik adalah media yang sangat digemari oleh anak. Oleh sebab itu seorang pelayan anak selain memperlengkapi dirinya dengan hal-hal rohani, juga perlu mengerti dan belajar tentang psikologi anak, mempelajari perkembangan teknologi, tahu 
menggunakan media-media elektronik, supaya pelayanannya tidak kalah menarik dengan apa yang ditawarkan oleh dunia.

Kelima, Gereja dan lembaga pelayanan anak perlu menyediakan fasilitator dan program-program yang dapat menunjang pertumbuhan anak secara holistik, yaitu memenuhi kebutuhan mereka secara rohani, mental intelektual, sosial - emosional dan secara fisik. 


\section{KEPUSTAKAAN}

Angel, Wawancara Oleh Penulis, (Makassar, 29 Mei 2011)

Dallas Willard, Renovation of the Heart, (Malang: Literatur SAAT, 2005)

Esti, Wawancara Oleh Penulis (Makassar, 28 Mei 2011).

I. L. Pasaribu dan B. Simanjuntak, Proses Belajar-Mengajar, (Bandung: Tarsito, 1983)

Inri, Wawancara oleh Penulis, Yogyakarta, Juli 2010.

Kamus Besar Bahasa Indonesia

Komaruddin, Kamus Riset, "Population (2), Populasi” (Bandung: Angkasa, 1984)

Komaruddin, Kamus Riset, "Sample, contoh, sampel” (Bandung: Angkasa,1984)

Lelia Lewis, Mengajar Untuk Mengubah Kehidupan (Bandung: Yayasan Kalam Hidup, 1995)

Masri Singarimbun \& Sofian Effendi, Metode Penelitian Survai, (Jakarta: LP3ES, 1985).

Mery Go Setiawani, Pembaharuan Mengajar, (Bandung: Yayasan Kalam Hidup, 2005).

Mohamad Ali, Penelitian Kependidikan Prosedur e Strategi, (Bandung: Angkasa, 1985).

Panduan Pembina Domby Kid's Hope 2, (Yogyakarta: Versi 1.0/2008).

Prof Dr. J. S. Badudu; Prof Sultan Mohammad Zain, Kamus Umum Bahasa Indonesia, (Pustaka Sinar Harapan: Jakarta, 1994).

Ruth Laufer, Metode-Metode Kreatif Untuk Pelayanan Remaja, (Malang: Yayasan Persekutuan Pekabaran Injil Indonesia, 1986).

Sutrisno Hadi, Metodologi Research 2, (Yogyakarta: Andi offset, 1990).

Tri Budiardjo, Sorotan Alkitab Tentang Anak, (Jakarta: Yayasan Obor Mitra, 2001).

Tri Nuryani, Wawancara oleh Penulis, Yogyakarta, 13 Mei 2011. 